Bryn Mawr College

Scholarship, Research, and Creative Work at Bryn Mawr College

Classical and Near Eastern Archaeology Faculty

Research and Scholarship

Classical and Near Eastern Archaeology

1982

\title{
Of Kouroi and Korai: Attic Variety
}

Brunilde S. Ridgway

Bryn Mawr College, bridgway@brynmawr.edu

Let us know how access to this document benefits you.

Follow this and additional works at: https://repository.brynmawr.edu/arch_pubs

Part of the History of Art, Architecture, and Archaeology Commons

\section{Custom Citation}

Ridgway, Brunilde. 1982. "Of Kouroi and Korai: Attic Variety." Hesperia Supplements 20: 118-127+209.

This paper is posted at Scholarship, Research, and Creative Work at Bryn Mawr College. https://repository.brynmawr.edu/arch_pubs/180

For more information, please contact repository@brynmawr.edu. 


\section{OF KOUROI AND KORAI-ATTIC VARIETY}

(Plate 17)

T HAVE LEARNED a great deal from Homer A. Thompson, through the years of my

acquaintance with him, and two of his teachings stand out with clarity in my mind: to pay attention even to minute details, and to rise above them to view the greater whole. The ensuing speculation and theories may not always be correct, but as long as they are revised whenever new and contradictory evidence becomes available, the attempt should be made. I hope that these lines, stemming from just such an approach, may not be amiss as a modest offering. The minute details to be considered here are a set of swollen ears and a mantle. The larger picture concerns the possible inferences on the meaning of kouroi and korai in Archaic Athens. ${ }^{1}$

The so-called Rayet Head (P1. 17:a) was found in Athens, "near the gas-works" at the edge of the Kerameikos cemetery, in the early 1870's, and is now one of the glories of the Archaic collection in the Ny Carlsberg Glyptothek in Copenhagen. Well known to scholars, the head is often illustrated in monographs on Greek sculpture and is analytically described in Richter's Kouroi. ${ }^{2}$ There, however, no mention is made of the fact that the head has "cauliflower ears" as befit a boxer (Pl. 17:b, c). ${ }^{3}$ Other descriptions comment on the thick, fleshy rendering of this anatomical detail, but treat it as a mannerism of its sculptor. ${ }^{4}$ I was able to inspect the Rayet Head in the spring of 1979 and

\footnotetext{
${ }^{1}$ Besides the standard abbreviations, the following will be used throughout:

$A G A=$ G. M. A. Richter, The Archaic Gravestones of Attica, London 1961

AMA $=$ H. Schrader, E. Langlotz, W.-H. Schuchhardt, Die archaischen Marmorbildwerke der Akropolis, Frankfurt am Main 1939

Archaic Style = B. S. Ridgway, The Archaic Style in Greek Sculpture, Princeton 1977

Jeffery $\quad$ L. H. Jeffery, "The Inscribed Gravestones of Archaic Attica," BSA 57, 1962, pp. 115153

Korai $\quad$ = G. M. A. Richter, Korai, Archaic Greek Maidens, London 1968

Kouroi $\quad=$ G. M. A. Richter, Kouroi, Archaic Greek Youths, London 1970

Olympic Games $=$ N. Yalouris et al., The Olympic Games, Athens 1976

Raubitschek = A. E. Raubitschek, Dedications from the Athenian Akropolis, Cambridge, Mass. 1949

Schmidt = G. Schmidt, "Kopf Rayet und Torso vom piräischen Tor," AthMitt 84, 1969, pp. 65-75

Schneider $\quad=$ L. A. Schneider, Zur sozialen Bedeutung der archaischen Korenstatuen, Hamburg 1975

Willemsen $=$ F. Willemsen, "Archaische Grabmalbasen aus der athener Stadtmauer," AthMitt 78, 1963, pp. 104-153
}

${ }^{2}$ Copenhagen, Ny Carlsberg Glyptothek I.N. 418; F. Poulsen, Catalogue of Ancient Sculpture in the Ny Carlsberg Glyptotek, Copenhagen 1951, no. 11, pp. 28-29, dated in the third quarter of the 6th century. Kouroi, no. 138, figs. 409, 410.

${ }^{3}$ The term is defined in Webster's Dictionary as "an ear deformed from injury and excessive growth of reparative tissue, so as to suggest a cauliflower." Boxers, wrestlers and pankratiasts would suffer such injuries in practicing their sport, either under the blows of their opponent or when the cartilage was broken by the pulling of the ear. Present-day boxers and wrestlers often display similar ear configuration (Pl. 17:d).

${ }^{4}$ See, e.g., Schmidt, p. 70: “ . . . das fleischige, wenig differenzierte, formelhafte Ohr ist bei Boxer und Kopf Rayet sehr ähnlich ..."; p. 75: "Das Ohr ist nicht mehr so kompakt fleischig gebildet wie bei dem Kouros-Kopf 
can verify that this is an iconographic, not a stylistic, trait. Specifically, the central orifice is quite small and the cartilage surrounding it (the antihelix) appears swollen, with creases marking the puffiness of the area, which is barely distinguished from the helix. ${ }^{5}$

This realistic rendering is well attested in 4th-century and Hellenistic sculpture; it was, however, generally surmised that it would not occur before the time of increased professionalism in sport and, specifically, of decreasing idealization in art. But the discovery of the so-called Boxer Stele in 1953 forced a revision of this dating: the relief can be ascribed to the mid-6th century B.C. on the bases of style and format, yet not only does the bearded man on the stele display cauliflower ears and a broken nose but his raised arm is clearly bound by the leather thongs of the boxer. ${ }^{6}$ The deceased is intentionally characterized as a mature athlete who survived many encounters, although it is perhaps unnecessary to speculate that he might have met his end in one last match.

This characterization, surprising as it might seem at this early a date, is not altogether out of place on a gravestone. In the large corpus of Attic stelai, several Archaic examples identify the deceased as an athlete, while others depict him as a warrior, a priest or a man of status. ${ }^{7}$ But I did not know of any similar individualization in sculpture in the round, specifically within the kouros type with its strict adherence to a neutral formula. I have therefore made an (admittedly superficial) examination of the ears of kouroi, without being able to find a close parallel to those of the Rayet Head. To be sure, several male figures have thick and rather shapeless ears, and it is impossible in many cases to determine whether the rendering is due to the early date or the small size of the sculpture, the relative lack of skill of the sculptor or the desire to depict a boxer's ear. In particular, it is not unusual to find that helix and antihelix are more or less on a level, thus suggesting a degree of swelling. My criterion in such cases has been the size of the opening into the middle ear: when normally large, I have assumed that no deformity was meant and that the ear pattern had just been simplified. In fact, some sphinxes and a few korai exhibit similar renderings. The Rayet Head stands apart. $^{8}$

\footnotetext{
..." (in comparison with the Potter's Relief on the Akropolis). For a more general statement see J. Boardman, Greek Sculpture, The Archaic Period, London 1978, p. 83: "thick ears".

${ }^{5}$ For terminology and a diagram of the human ear see Kouroi, p. 17.

${ }^{6}$ Boxer Stele: $A G A$, no. 31, fig. 92; Jeffery, p. 128 , Stelai, no. 1. She, however, interprets the nose as possibly hooked rather than definitely broken.

${ }^{7}$ On characterization on stelai see Archaic Style, p. 169; cf. also p. 167. For various examples see $A G A$, nos. 25-27 (athletes); 45, 46, 67 (warriors); 70 (priest or man of status).

Comments on the individualization of grave stelai and the youth of the kouroi during the Archaic period are also made by B. Schmaltz, "Verwendung und Funktion attischer Grabmäler," MarbWinckPr, 1979, pp. 13-37; see especially pp. 35-36, where the Rayet head is mentioned as having swollen ears for characterization. My point of view as regards the kouroi is somewhat different.

${ }^{8}$ One possible example of cauliflower ear would be even earlier than the Boxer Stele: the head from the Ptoion, Athens N.M. no. 15; Kouroi, no. 10, fig. 75 ( $\mathrm{ca} .580$ B.c.). Only the left ear appears deformed, but this is not unusual in later times (see footnote 28 below). A break and an imperfection in the stone cross the feature, however, and may have been responsible for the undetailed rendering.
} 
Because of its alleged findspot, the Copenhagen Head is likely to have belonged to a funerary statue, since many such monuments lined the road to Peiraieus near the homonymous Gate. Several of them were incorporated into a stretch of the Themistoklean Wall in the vicinity and were excavated by J. Threpsiades in $1953 .{ }^{9}$ Among them are the fragmentary torso and parts of the legs of a kouros which G. Schmidt has connected with the Rayet Head. ${ }^{10}$ The latter, although larger than life-size, may be too small for the body, ${ }^{11}$ and the torso, at least in its present state, displays no specific athletic connotation. The attribution of head to body remains uncertain. The fragmentary kouros has also been tentatively associated with an inscribed base for a Samian, or with another set up for the Karian Tymnes, ${ }^{12}$ but no joins exist. In turn, the $\mathrm{Ny}$ Carlsberg Head has been attributed to the as yet unidentified statue which stood once on the so-called Ball Players Base in the Athens National Museum, also found near by. ${ }^{13}$ That athletic contests, including wrestling, should be depicted on the pedestal of a figure characterized as a boxer or a pankratiast seems particularly appropriate, but again certainty is lacking; moreover, the Rayet Head may be too early (ca. 530?) for a base generally placed within the last decade of the 6th century.

It has so far been assumed that the Rayet Head belonged to a kouros-type statue; I wonder whether this was indeed the case. As late as the impressive Aristodikos (ca. 490) the standard formula for the nude male grave statue seems to have been retained, and I have argued elsewhere that it may have borne little resemblance (in age, physiognomy or otherwise) to the deceased it commemorated. ${ }^{14}$ A kouros, originally a representation of Apollo, would have remained a symbol of heroization, while greater sense of identity was attained by depictions on stelai. Toward the end of the 6th century, with the widespread interest in the Panathenaic Festival and the Olympic Games,

${ }^{9}$ Besides the general account in Jeffery, pp. 126-128, see also Willemsen, and Archaic Style, pp. 292-

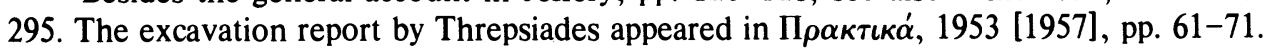

${ }^{10} \mathrm{Schmidt}$, pl. 32. The torso is preserved approximately from waist to mid-thighs, the non-joining right leg preserves the lower thigh and the knee, the left extends from mid-kneecap to ankle. According to early reports, a foot had been found with the Rayet Head but is now lost; this information, however, may serve to discredit the further association of a plinth with a kouros' feet: Schmidt, p. 73, and W. Deyhle, "Meisterfragen der archaischen Plastik Attikas," AthMitt 84, 1969, pp. 1-57, especially p. 29. On the body fragments per se see U. Knigge, "Zum Kouros von piräischen Tor," AthMitt 84, 1969, pp. 76-86, pls. 33-35.

${ }^{11} \mathrm{Cf}$. Schmidt, pl. 31 , p. 69 and note 18 , where the relative proportions are said to be at least not incompatible.

${ }^{12} \mathrm{Cf}$. Schmidt, pp. 73-74 and notes 39, 41, 42; Knigge, op. cit. (footnote 10 above), pp. 85-86. For a discussion of the bases see Willemsen, pp. 123-129.

${ }^{13}$ See Schmidt, p. 73 , note 37 , and Willemsen, p. 135. Note that not only the Ball Players Base was found in that general area but also the Boxer Stele and the so-called Marathonomachos Stele: Jeffery, $p$. 128, Stelai, no. [2]. Since the helmeted youth is usually taken to be a hoplitodromos or a pyrrhic dancer, the monuments from that vicinity would seem to be particularly connected with athletic representations. For the monument of an Olympic victor see Willemsen, pp. 110-117; cf. also his pp. 129-136, for another rendering of the ball-playing scene on a different base. Jeffery, p. 123, no. [4], lists the Rayet Head as coming from a slightly different area, but see her statement on p. 116.

${ }^{14}$ Aristodikos: Kouroi, no. 165, figs. 492, 493. My comments are in Archaic Style, pp. 49-59, 77. Cf. also Jeffery, p. 150. 
victors' statues began to be erected-some in the increasingly popular medium of bronze, but some still in marble. In either case, their composition may have been more animated than the traditional kouros pose, as suggested by some bases and even some "narrative" monuments from the Athenian Akropolis. ${ }^{15}$ The same transformation may have taken place among funerary statues, and the Rayet Head could indicate that it occurred as early as ca. 530. Although the more symbolic and static kouros continued to mark graves until almost the end of the Archaic period, a new athletic type may have existed side by side with it, eventually replacing the generic kouros entirely and giving rise to the long line of Severe athletes known in both life- and under life-size.

The Rayet Head has not been convincingly attributed to any of the known Archaic masters active in Athens, although stylistic similarities with the Boxer Stele, the Potter's Relief and the Ball Players Base have been pointed out. Endoios and Aristokles are known to have made monuments for burials in the vicinity of the Peiraieus Gate. ${ }^{16}$ More significantly, tombs for foreigners seem to have been gathered in that particular area, as indicated by the Karian and Samian epitaphs already mentioned. Perhaps the characterization of an athlete's statue was prompted by the wishes of a family from Asia Minor, where wrestling was almost the national sport. The literary sources tell us that the Olympic rules for boxing were established by Onomastos of Smyrna, the first Olympic winner of the event in 688, and that Pythagoras of Samos, who won in 588, was the first scientific boxer. ${ }^{17}$

Cauliflower ears, although with less picturesque language, are also mentioned by the ancient authors. Plato refers to young oligarchs "with broken ears," who imitated

${ }^{15}$ Pausanias (VI.18.7) seems to ascribe the first victors' statues to the late 6th century; cf. C. Mattusch, "The Berlin Foundry Cup," AJA 84, 1980, p. 443 and note 46. P. Levi, in his Pausanias: Guide to Greece II, London [Penguin Books] 1971, p. 337, note 152, comments that a 7th-century victor's statue had already been mentioned by Pausanias at Olympia, but that "Probably it was a stiff, massive, primitive Pharaoh-like figure, and Pausanias was instinctively not thinking of it as an athletic portrait." This would imply that the later statues looked different from the standard kouros.

For an analysis of male statues found on the Athenian Akropolis see Archaic Style, p. 49, note 3. Raubitschek (pp. 80-82, no. 76) has suggested that the inscribed base E.M. 6379 held a dedication by Phayllos of Kroton, who mentions that he won the pentathlon at Delphi three times; the base supported a marble statue but apparently one more complex than a standard kouros. Raubitschek tentatively associates with it the so-called Blond Boy (Akr. 689). I would question the Blond Boy as a depiction of a pentathlete because of his elaborate hairstyle, unless he represented Theseus and thus only symbolically alluded to Phayllos' prowess. For other comments on victors' monuments see Raubitschek, p. 464. For a typical animated group, perhaps Theseus wrestling Skyron, see $A M A$, no. 410, pp. 281-283 and figs. 326, 327, pls. 155-157 (Akr. 145).

${ }^{16}$ The stylistic grouping of the Rayet Head had already been attempted by Poulsen (footnote 2 above). Boardman (footnote 4 above) seems to accept the connection with Endoios' workshop; cf. Deyhle (footnote 10 above), pp. 13-20 (Endoios); Schmidt; and Willemsen, p. 135.

${ }^{17}$ It is impossible to differentiate between a boxer's and a wrestler's ears; cf. footnote 3 above. For Onomastos of Smyrna see Philostratos, de gymnastica, 12; for Pythagoras of Samos see Diogenes Laertius, VIII.47. These references are given by H. A. Harris, Greek Athletes and Athletics, London 1964, p. 98 and note 49 on p. 206. For an Archaic relief with fat wrestlers from a Lycian tomb see E. Akurgal, Die Kunst Anatoliens, Berlin 1961, p. 135, fig. 86. See also B. Schröder, Der Sport im Altertum, Berlin 1927, pl. 23, for coins of Aspendos showing wrestlers. 
the Spartans in their fashions (including boxing) in order to publicize their political inclinations. ${ }^{18}, \mathrm{~A}$ boxer's physique is described as otothladias. ${ }^{19}$ Various gods and heroes are cited as the mythical predecessors of the Olympic athletes. Theseus, although supposedly the inventor of wrestling, is shown with normal ears, even when his opponent sometimes clearly exhibits the disfigurement. ${ }^{20}$ Apollo, another "inventor", was credited with outboxing Ares at Olympia. ${ }^{21}$ I have been unable to find a sure representation of Apollo with cauliflower ears, but the Ares Ludovisi type, at least as reproduced by Roman copyists, definitely displays the deformity. ${ }^{22}$

Herakles is shown with swollen ears as early as the Severe period. In the metope with the Nemean Lion, from the Temple of Zeus at Olympia, the hero is depicted young and tired after his first labor, and with the obviously swollen ears of the boxer; yet the subsequent metopes, as far as we can tell in their present state of preservation, omit this characteristic. ${ }^{23}$ Perhaps the Struggle with the Lion was so close to a typical wrestling bout in its traditional iconographic schema that the Olympia master, although electing to show a later moment in the event, wanted to allude to the more familiar version. Conversely, the hero might have been portrayed progressively less human and more divine. Among the other sculptures from the same building, the Lapith being bitten by a Centaur, on the West pediment, has cauliflower ears, while the Centaur being grabbed by the ear exemplifies the tackle which causes that kind of damage. ${ }^{24}$ The rendering is therefore well attested by ca. 460 B.C. in undoubted Greek originals.

For the later periods our evidence increases, although some examples remain questionable. On the Parthenon frieze several riders seem to have swollen ears, ${ }^{25}$ and the youthful head with a lion-skin helmet from the Tegea Temple has them beyond doubt. ${ }^{26}$ The best known example is perhaps the bronze Boxer in the Terme Museum in Rome; by the Roman period cauliflower ears identify primarily the professional, ${ }^{27}$ but

${ }^{18}$ Plato: Gorgias, 515e; Protagoras, 342b 8; cf. the comments by E. R. Dodds, Plato, Gorgias, Oxford 1959, p. 357.

${ }^{19}$ Otothladias: Diogenes Laertius, v.67, speaking about the philosopher Lyko; Yalouris (Olympic Games, p. 222) cites it as a boxer's name. For the effects of the palaistra on ears: Philostratos, Heroicus, 167.13.

${ }^{20}$ Olympic Games, pp. 82 and 202; fig. 108 illustrates a red-figured cup by the Kodros Painter, from Vulci, in the British Museum: London E 84, Beazley, $A R V$, p. 739, no. 4, ca. 430 B.C. Theseus, with normal ears, is fighting Kerkyon, who has a swollen ear.

${ }^{21}$ Olympic Games, pp. 35, 82, and 216.

${ }^{22}$ Ares Ludovisi: see S. Lattimore, "Ares and the Heads of Heroes," $A J A$ 83, 1979, pp. 71-78, especially pl. 3 , figs. 4,5 , pl. 6 , fig. 13 .

${ }^{23}$ Herakles and Nemean Lion: B. Ashmole and N. Yalouris, Olympia, London 1967, fig. 147; contrast the rendering of the ear in fig. 145. Only the Herakles of the metope with the eighth labor, the Mares of Diomedes, may have the same swollen rendering: Olympia, fig. 177. 74.

${ }^{24}$ Lapith, West Pediment, Figure Q: Olympia, fig. 88. Centaur, West Pediment, Figure D: Olympia, fig.

${ }^{25}$ Parthenon Frieze: see, e.g., F. Brommer, Der Parthenonfries, Mainz 1977, pls. 131 (S XIII), 135 (S XVII). Some such ears may occur also on the Lapiths and Centaurs of the South metopes but I cannot be sure.

${ }^{26}$ Tegean Head: A. F. Stewart, Skopas of Paros, Park Ridge, N.J. 1977, cat. no. 16, pl. 13:b and pl. 52, ear 2 .

${ }^{27}$ Terme Boxer: Olympic Games, fig. 120; Roman boxers and practices, ibid., pp. 275-285 and fig. 153. 
a few Greek citizens continued to have themselves so portrayed during the Empire. ${ }^{28}$ Conversely, the Etruscans do not seem to have imitated Greek art in this respect. ${ }^{29}$ The Rayet Head, if not the first, may represent one of the earliest examples of this rendering in Greek sculpture in the round, in the shift from the funerary-Apollo/anonymous-kouros representation to the more individualistic portrayal of athletes.

The question raised about the varying meaning of the kouros type in Attica can also be formulated about the Akropolis korai, and although my comments must remain considerably more tentative than in the case of athletic figures, some points are perhaps worth making.

I had shared in the general surmise that these elegant female dedications (Pl. 17:e) on the Athenian citadel represented generic attendants to Athena, whether priestesses, ergastinai or arrephoroi ${ }^{30}$ Specifically, I accepted the theory that they displayed contemporary fashions of the Athenian aristocracy, regardless of whether they depicted actual Athenian girls or were simply pleasing images often donated by men. A monographic study has even affirmed that these smiling creatures were the social expression of the upper class and of a city state where women lent prestige to their husbands. They would have been rendered as they appeared at festivals, the normal showcase for female beauty, as sung by the lyric poets. ${ }^{31}$ I have now had occasion to re-examine the issue and have come to question the diagonal mantle as an item of clothing worn by Athenian women during the 6th century.

In chronological order, the facts seem to fall in this sequence:

1) The Athenian women used to wear a dress fastened with long pins; when they turned these ornaments into weapons to kill the sole survivor of the Battle of Aigina, they were made to change fashions and to adopt "Karian dress" as defined by Herodotos. ${ }^{32}$ This statement has usually been taken to mean that women shifted from peplos to a chiton/diagonal-himation combination. ${ }^{33}$ The Battle of Aigina is poorly dated but seems to have occurred still in the 7th century. If this is the true nature of the change, it is not reflected in any definite way either in vase painting or in sculpture. Perhaps the

${ }^{28}$ E. B. Harrison, The Athenian Agora, I, Portrait Sculptures, Princeton 1953, no. 14 and note 2; no. 25, note 11 . The rendering is limited to only one ear.

${ }^{29}$ This conclusion was reached by Sarah U. Wisseman in her Bryn Mawr College dissertation (1981): The Archaeological Evidence for Etruscan Games.

${ }^{30}$ Archaic Style, pp. 50, 108-112; see also the review by A. F. Stewart, ArtB 62, 1980, p. 486. Since I have discussed the costume of the korai at some length in my book, I shall limit myself to brief allusions here.

${ }^{31}$ Schneider, passim. See especially pp. 27-29 for the smile as a social expression of the upper class, typical of the gods and therefore making man "godlike". Appendix 1, on vase paintings where korai appear as spectators to heroes' deeds, suggests that they function as indication of the hero's aristocratic milieu, not as literal participants to the scene.

${ }^{32}$ Herodotos, v.87, where mention is made only of linen tunics, and his footnote, where the dress is called Karian.

${ }^{33}$ E.g., Korai, pp. 9-10. The change is dated to ca. 560 and attributed to both the Ionian leanings of Peisistratos and to the anecdote mentioned by Herodotos, with a consequent lowering of the date of the Battle of Aigina. 
change implied only the adoption of the chiton under a heavy, symmetrical mantle, such as we see on one of the earliest Athenian korai, Akr. 593. ${ }^{34}$

2) The earliest korai with diagonal himation on the Akropolis ( $c a .560$ B.C.) are imports or works by foreign masters: Akr. 619 and 677 are probably Cycladic; other, later statues are Chian (Akr. 675); and the activity of Lakonian (Gorgias) and possibly Ionian (Bion, Endoios) masters is attested by surviving signatures on dedications. ${ }^{35}$ That the diagonal mantle was at home in Asia Minor is not in question, although we cannot be sure whether it was worn by humans or by cult images (Artemis?). The literary sources conveniently collected by Schneider usually refer only to the trailing chiton, or use more generic terms. In addition, most of the poets quoted belong to Ionia or the islands.

3) By ca. 540 the wide distribution of the diagonal himation in all territories and colonies inhabited by Greeks-regardless of climate-is surprising, especially since the garment seems a latecomer within Archaic fashions, or at least it can be said not to coincide with the beginning of monumental sculpture. Perhaps the reason for the diffusion should be sought in the means of transmission: not in terms of the clothes per se but of the many terracotta statuettes reproducing divinities, which reached even the Western Greeks as copiously as those in Greece proper. If these statuettes depicted cult images or Nymphs or other non-human beings of some kind, fidelity in reproducing the costume may have been considered essential, although not paralleled by contemporary daily fashions. ${ }^{36}$

4) The earliest Attic kore from the Akropolis to display the diagonal mantle wears it with peculiar draping: the so-called Lyons Kore ( $c a$. 540) shows no indication of fasteners for the himation, and the rendering cannot be coherently explained. Later Akropolis korai continue to show unusual variations: the himation appears to be in two pieces, fastened along both shoulders (Akr. 605, 611, 678); or it is buttoned along the right arm but then again pinned once over the left shoulder (Akr. 600 and 673); or it hangs with balancing swags under both elbows, in unexplainable fashion (Akr. 685; Pl. 17:e). ${ }^{37}$ The diagonal border between the breasts is ornamented with an abundance of frills that often defy understanding unless they were separately applied to the folded garment.

5) It may be coincidence due to the chance of the finds, but none of the funerary korai from Attica, both earlier and later than the Lyons Kore, wears the diagonal him-

${ }^{34}$ Kore Akr. 593: Archaic Style, pp. 104-105, fig. 29 and bibliography on p. 118. For the date of the Battle of Aigina see, e.g., J. B. Bury, A History of Greece, 3rd ed., London 1955, p. 204, "probably near the middle of the seventh century." L. H. Jeffery (Archaic Greece, London 1976, p. 84) would go as early as the second half of the 8th century B.C.

${ }^{35}$ For a discussion of these korai see Archaic Style, pp. 104, 106, 118; the masters are mentioned on pp. 285-286 and in note 3 .

${ }^{36}$ The idea of a famous cult statue in Miletos as a possible prototype for the East Greek korai has already been advanced: B. Freyer-Schauenburg, Samos, XI, Bildwerke der archaischen Zeit und des strengen Stils, Bonn 1974, p. 47; Archaic Style, p. 98.

${ }^{37}$ Lyons Kore: Archaic Style, pp. 105-106; the other renderings of the himation: pp. 92, 94. 
ation. I once suggested that they are depicted with indoor attire, ${ }^{38}$ but the difference may be of another nature. Korai from the Citadel wearing just the chiton are also known, and may indicate that not all female statues should be interpreted in similar manner; in particular, Akr. 683, the Red-slippers Kore, was probably the smaller figure in a double dedication (by two men) which may therefore have had additional meaning, such as that of a human votary next to a goddess. ${ }^{39}$

6) The inception of the fashion (diagonal himation) has been connected with Peisistratos' ties with Ionia; ${ }^{40}$ yet the real popularity of the mode seems to occur after Peisistratos' death, toward the end of the 6th century. According to statistics worked out by A. Raubitschek and E. B. Harrison, approximately half of all surviving dedications to the Akropolis for the 6th and 5th centuries were made between 500 and 480 . Of the 56 more or less preserved korai catalogued by Langlotz, most were made between 530 and 490, and Ionic influence seems confined to them. The dedicators of offerings on the Akropolis included some members of the aristocracy, but among the 18 women there were, remarkably, a washerwoman and an Ionian who used a Chian sculptor. Korai were set up by a potter, a fuller and a tanner. ${ }^{41}$

7) The period around 530 coincides also with a marked increase in the number of extant Panathenaic amphoras. A study by J. R. Brandt concludes that during the rule of Peisistratos the Panathenaic Festival seems to have undergone decline and stagnation rather than expansion, to judge from the number of extant vases. Standardization in the pattern of the amphoras coincides with the rule of Peisistratos' sons, who may have used the expansion of the event as a political means to re-establish friendship with the alienated aristocracy. ${ }^{42}$ Korai earlier than 530 B.C. are therefore less likely to have represented aristocratic ergastinai or arrephoroi, and those which followed should not have varied in their meaning. ${ }^{43}$

8) Attic black-figured vases before the last quarter of the 6th century do not depict a diagonal himation, although the garment had already been seen on the Akropolis.

${ }^{38}$ Archaic Style, p. 103.

${ }^{39}$ Archaic Style, p. 107 and note 28, fig. 19; see also index for additional mentions and bibliography.

${ }^{40} \mathrm{Korai}$, pp. 9-10.

${ }^{41}$ Raubitschek, pp. 464-467, especially p. 465; the washerwoman: no. 380 (dedicated a basin); the Ionian woman: no. 3; the potter: no. 197; the fuller: no. 49; the tanner: no. 58. E. B. Harrison, The Athenian Agora, XI, Archaic and Archaistic Sculpture, Princeton 1965, p. 8 and note 49.

42 J. Rasmus Brandt, "Archaeologia Panathenaica I: Panathenaic Prize-vases from the sixth century B.C.," Acta ad Archaeologiam et Artium Historiam Pertinentia, Institutum Romanum Norvegiae 8, 1978, pp. 1-23, especially p. 19 and notes 6 and 11.

${ }^{43}$ We have no definite depiction of the Arrephoroi, even from later times, since the Erechtheion Karyatids, occasionally identified as such, hardly qualify. A fragmentary hydria by the Kleophon Painter in the collection of the University of Tübingen, E 112, supposedly shows Aphrodite between arrephoroi: Stewart, loc. cit. (footnote 30 above); AthMitt 93, 1978, pl. 13:2. The young women, however, are not distinguished by objects carried on their heads (as described by Pausanias), and they wear mid-5th-century costumes. The only comparable trait may be the gesture of the first woman on the left, who lifts her (long) himation: perhaps a misrepresentation of the pose of the korai, or an allusion to the Charites and the Horai, more appropriate companions to Aphrodite. 
Conversely, the fashion is rendered in red-figure scenes, but most of them are, either openly or possibly, mythological in content. It is becoming increasingly apparent that even what we take to be representations of daily life may have had heroic connotation for the contemporary user. ${ }^{44}$ It seems difficult to reconcile the tempo of fashions in vase painting and sculpture. Certainly nothing in the techniques made it inherently impossible for a black-figure painter to depict a diagonal himation or particularly appropriate for a red-figure master to do so.

9) Figures of non-human nature are clearly shown with the diagonal himation: the korai flanking the chariot of Apollo on the East pediment of his temple at Delphi-a site which has otherwise yielded no freestanding kore; the maidens on either side of the central floral akroterion on the Temple of Aphaia at Aigina-a position usually reserved for creatures of the air or at least endowed with special motion; Nikai at a variety of sites, including the Akropolis. It should also be stressed that the diagonal ruffle becomes the distinctive trait of archaistic sculpture and that perirrhanterion-holders, idols and karyatids are often depicted wearing such a mantle. Even when the costume actually shown is the peplos, the lower hem is treated as if it were part of a diagonal himation, a sign of venerability and antiquity. It seems remarkable that such a widespread fashion should be abruptly dropped from sculpture everywhere at the inception of the Severe style, just when statues became personalized rather than generic, and that the few examples, either in the round or in relief, which retain the diagonal mantle betray their later date only because of archaistic features. ${ }^{45}$

All this evidence is undoubtedly circumstantial and I want to stress once again the extremely tentative nature of my suggestions. It is nevertheless worth considering the possibility that the diagonal himation originated in Asia Minor, perhaps as part of the dress of a famous cult image and maybe even under Anatolian influence. From there the motif, carrying the same religious connotation, was distributed throughout the Greek cities. On the Athenian Akropolis the garment arrived through the dedications of foreigners, carved by foreign masters. When the Athenians imitated it, they did so with some misunderstanding, since the fashion was not current in their city. The elaborate dress became the hallmark of a "non-human" image, thus appropriate as a dedication to a divinity that could then be offered by aristocracy and lower classes alike. The garment disappeared in the Severe period, when each statue became individually characterized, but was retained in archaistic art through the centuries.

If all the above is near the mark, to the question "Who are the Akropolis Korai?" we should answer: "Not Athenian aristocratic girls, ergastinai or arrephoroi, but Nymphs

${ }^{44}$ See, e.g., J. Neils, "The Group of the Negro Alabastra," AntK 23, 1980, pp. 13-23, esp. p. 23; idem, "The Loves of Theseus: An Early Cup by Oltos," $A J A$ 85, 1981, pp. 177-179.

${ }^{45}$ If fashions in sculpture are taken as true reflection of daily life, the change to the Severe peplos must coincide with a change in costume in Athens and everywhere else. Patriotic reasons might have prompted the rejection of an eastern garment, but this explanation seems less valid outside Greece proper, and in any case it is not reflected in Attic red-figured vases until some years later. On Archaistic fashions see Harrison, op. cit. (footnote 41 above), pp. 51-61; Archaic Style, chap. 11 and esp. pp. 313-316 and, on the Archaic korai, pp. 113-114. 
or lesser deities in distinctive attire; they may have originally portrayed a major goddess, but their meaning became diluted into generality in the course of the 6th century in Athens."

BRUNILDE SISMONDO RIDGWAY

BRYN MAWR COLLEGE

Department of Classical and Near Eastern Archaeology

Bryn Mawr, PA 19010 


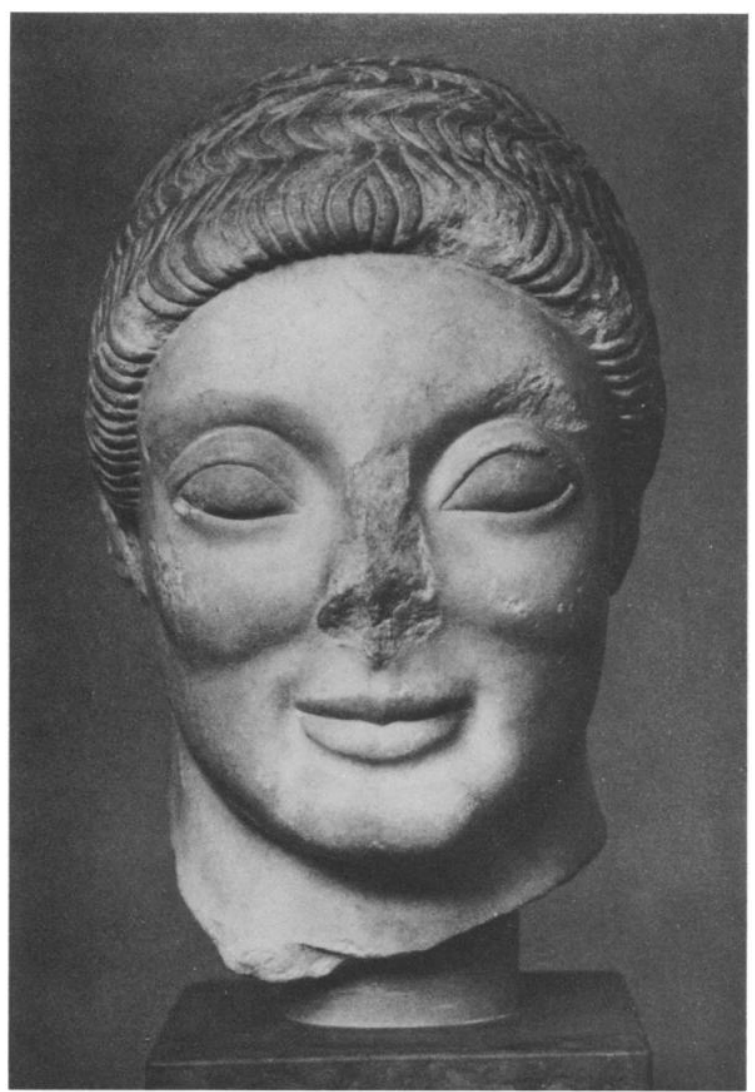

a. The Rayet Head, Copenhagen, Ny Carlsberg Glyptothek

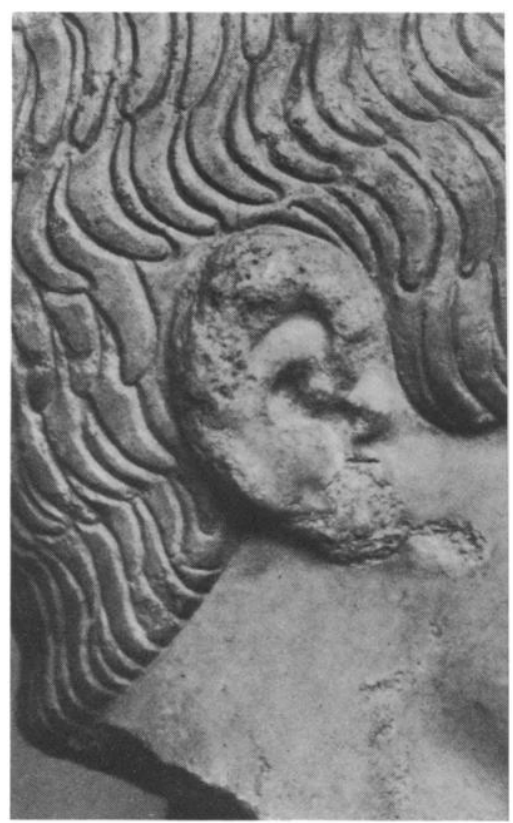

b. Rayet Head, right ear

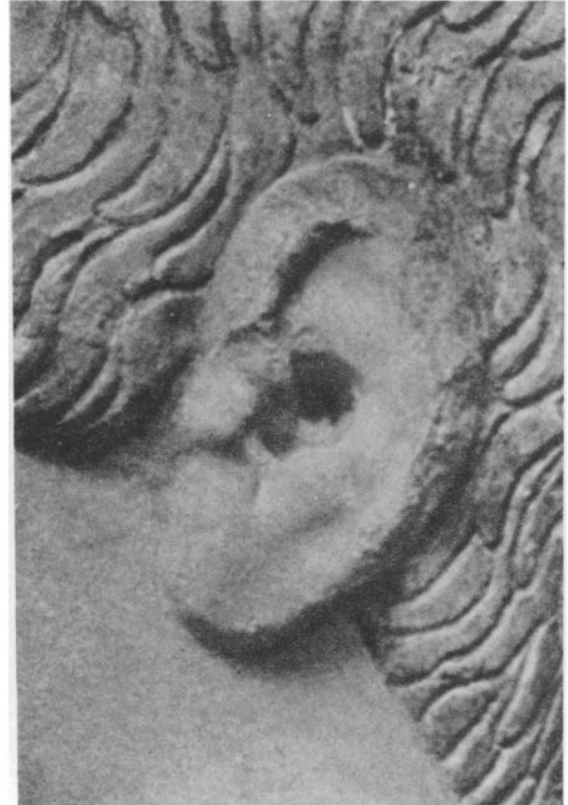

c. Rayet Head, left ear

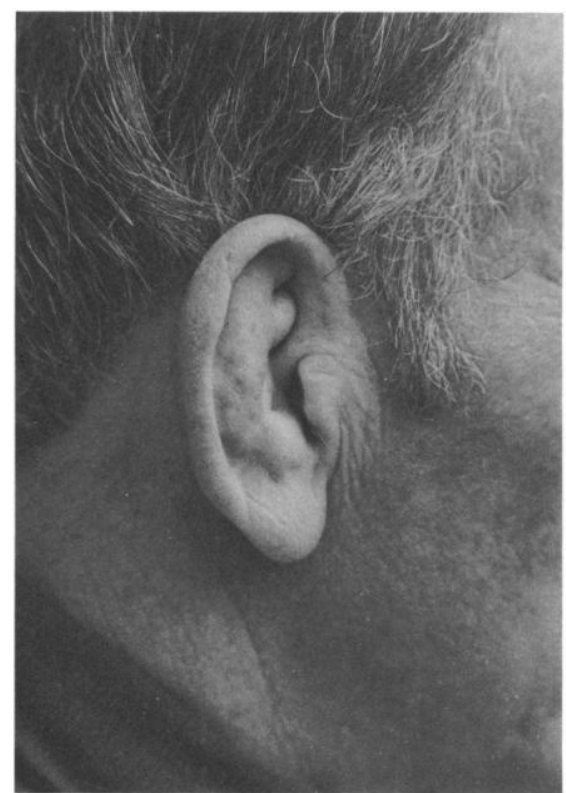

d. A modern cauliflower ear. Photo courtesy of Douglas Nigro

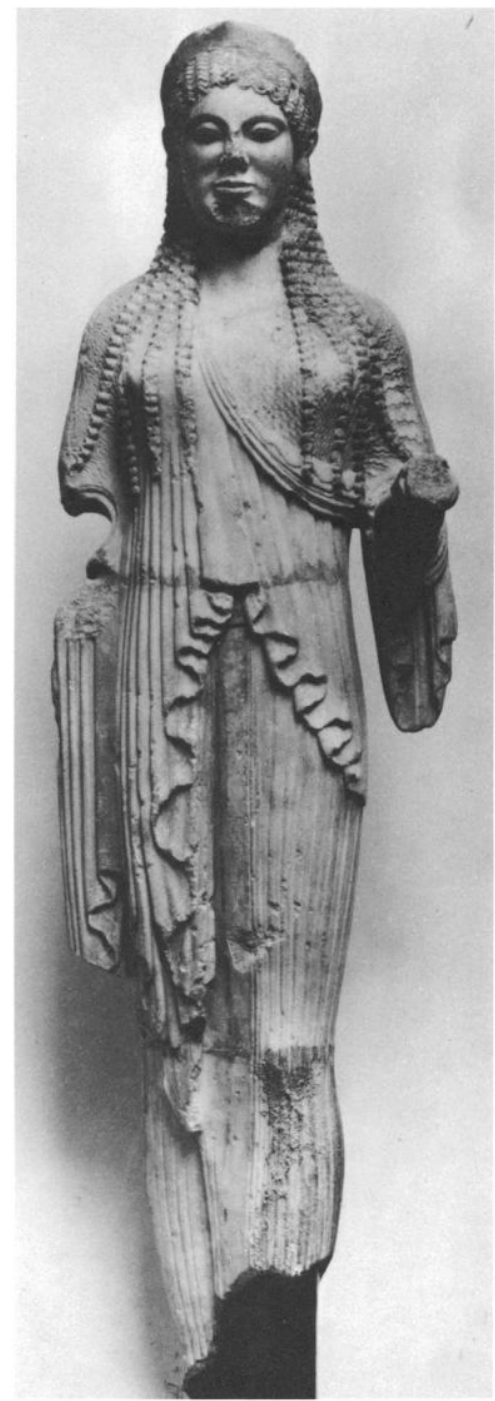

BRUNILDE S. RIDGWAY: OF KOUROI AND KoRAI, ATTIC VARIETY 